Article

\title{
Plant Growth and Water Purification of Porous Vegetation Concrete Formed of Blast Furnace Slag, Natural Jute Fiber and Styrene Butadiene Latex
}

\author{
Hwang-Hee Kim $^{1}$ and Chan-Gi Park ${ }^{2, *}$ \\ 1 Research Institute of Technology, Nature and Environment Co. Ltd., 116-28 Boheung-1Gil, \\ Kongju 32533, Korea; hwanghekim@hanmail.net \\ 2 Department of Rural Construction Engineering, Koungju National University, 54 Daehak Street, \\ Yesan 32439, Korea \\ * Correspondence: cgpark@kongju.ac.kr; Tel.: +82-41-330-1266; Fax: +82-41-330-1269
}

Academic Editor: Vincenzo Torretta

Received: 29 February 2016; Accepted: 15 April 2016; Published: 20 April 2016

\begin{abstract}
The purpose of this study is to investigate porous vegetation concrete formed using the industrial by-products blast furnace slag powder and blast furnace slag aggregates. We investigated the void ratio, compressive strength, freeze-thaw resistance, plant growth and water purification properties using concretes containing these by-products, natural jute fiber and latex. The target performance was a compressive strength of $\geqslant 12 \mathrm{MPa}$, a void ratio of $\geqslant 25 \%$ and a residual compressive strength of $\geqslant 80 \%$ following 100 freeze-thaw cycles. Using these target performance metrics and test results for plant growth and water purification, an optimal mixing ratio was identified. The study characterized the physical and mechanical properties of the optimal mix, and found that the compressive strength decreased compared with the default mix, but that the void ratio and the freeze-thaw resistance increased. When latex was used, the compressive strength, void ratio and freeze-thaw resistance all improved, satisfying the target performance metrics. Vegetation growth tests showed that plant growth was more active when the blast furnace slag aggregate was used. Furthermore, the use of latex was also found to promote vegetation growth, which is attributed to the latex forming a film coating that suppresses leaching of toxic components from the cement. Water purification tests showed no so significant differences between different mixing ratios; however, a comparison of mixes with and without vegetation indicated improved water purification in terms of the total phosphorus content when vegetation had been allowed to grow.
\end{abstract}

Keywords: by-product materials; blast furnace slag aggregates; latex; void ratio; plant growth; porous vegetation concrete; water purification

\section{Introduction}

Ecosystem restoration has received growing attention in recent years, and there have been many and diverse investigations of the properties of concretes, including porous vegetation concrete [1-4]. Plant growth is inhibited in concrete because of the limited space for rooting and sprouting, the low water permeability and retentivity, and the low nutrient content [5-8]. Porous vegetation concrete allows water and nutrients to be supplied, enabling plant growth [9-11]. Also, $\mathrm{CO}_{2}$ emissions are becoming an increasingly pressing concern because of the threat of global warming $[5,12,13]$. The concrete industry is seeking measures to reduce $\mathrm{CO}_{2}$ emissions, as $\mathrm{CO}_{2}$ emissions from cement manufacturing contribute to about $5 \%-15 \%$ of global $\mathrm{CO}_{2}$ emissions [12-14]. Therefore, a significant reduction in cement use would be an effective way to reduce $\mathrm{CO}_{2}$ global emissions [13]. The $\mathrm{CO}_{2}$ emissions associated with the production of 1 ton of cement are approximately $870 \mathrm{~kg}$, and methods to 
reduce the use of cement in concrete are urgently required [5,13]. If cement could be replaced with blast furnace slag cement, it would be particularly effective in reducing global $\mathrm{CO}_{2}$ emissions $[13,14]$.

Crushed stones are widely used as aggregates in the production of concrete; however, there are a number of environmental problems (destruction of natural rock, rock mountain, and forest resources, etc.) associated with this technique, and other aggregates are being sought [11,15]. Blast furnace slag aggregates are a by-product of the steel industry; if they could be used as a substitute for crushed stone, they would be particularly effective for resource-recycling.

There have been a number of investigations of the use of porous vegetation concrete for river revetments, obtaining a vegetation effect as well as a water purifying effect $[6-8,16,17]$. Here, blast furnace slag powder was used, with a mixing ratio of up to $60 \%$ of the mass of cement. This study investigated the effects on the physical and mechanical properties of porous concrete, as well as the water purification performance. This study also investigated the addition of styrene butadiene (SB) latex and natural jute fiber, as well as the substitution of crushed aggregates with coarse blast furnace slag aggregates.

\section{Materials and Methods}

\subsection{Materials}

The blast furnace slag cement used in this study had a $60 \%$ substitution rate of blast furnace slag; its physical properties are listed in Table 1 . The blast furnace slag aggregates exhibited a grain size in the range $8-25 \mathrm{~mm}$, as shown in Figure 1, and the physical properties of the blast furnace slag aggregate are listed in Table 2. During steel production, blast furnace slag aggregates is formed at temperatures in excess of $1500^{\circ} \mathrm{C}$. Also, Blast furnace slag aggregates does not include harmful heavy metals such as $\mathrm{Cr}$ or $\mathrm{Pb}[18]$.

Table 1. Physical properties of blast furnace slag cement.

\begin{tabular}{ccc}
\hline Properties & Value \\
\hline Fineness $\left(\mathrm{cm}^{2} / \mathrm{g}\right)$ & 4330 \\
Density $(\mathrm{kg} / \mathrm{L})$ & 3.02 \\
Stability (\%) & 1 \\
\hline \multirow{2}{*}{ Setting time (Gillmore needle) } & Initial set (min) & 265 \\
& Final set (hour:min) & $6: 15$ \\
\hline \multirow{2}{*}{ Compressive strength $(\mathrm{MPa})$} & 3 day & 20.6 \\
& 7 day & 29.8 \\
& 28 day & 54.5 \\
\hline
\end{tabular}

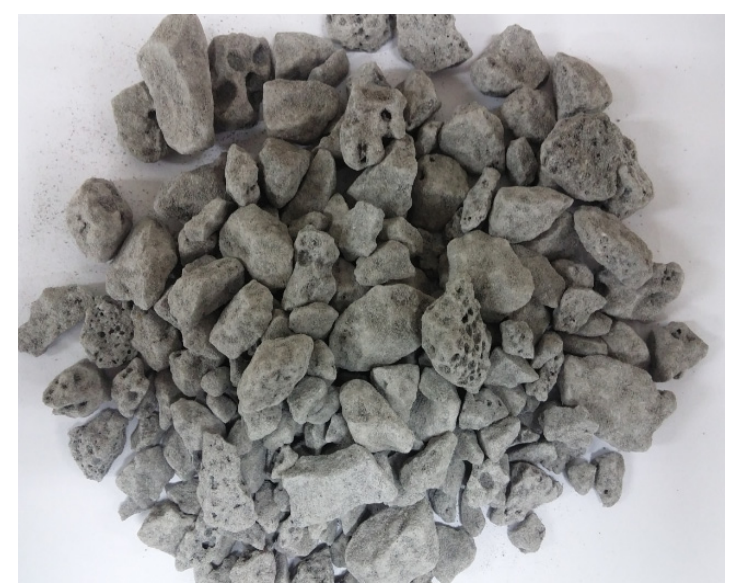

Figure 1. Blast furnace slag aggregates. 
Table 2. Physical properties of coarse aggregate.

\begin{tabular}{ccc}
\hline Properties & Blast Furnace Slag Aggregate & Crushed Aggregate \\
\hline Density (kg/L) & 2.36 & 2.65 \\
Water absorption ratio (\%) & 5 & 0.35 \\
Fineness modulus & 6.75 & 6.92 \\
\hline
\end{tabular}

When industrial waste contaminates either underground water aquifers or surface water, serious environmental problems may result, including soil and water contamination. Therefore, it is important to carry out environmental analyses. Here, this study carried out heavy metal elution tests on the blast furnace slag aggregates according to the standard of waste process test [19], as listed in Table 3. None of the items listed in Table 3 were detected except for oil; the oily component was $<0.1 \%$, which satisfies the standard (of $\leqslant 5 \%$ ). The oil is contained in the blast furnace aggregate by the machine in the course of crushing the blast-furnace slag. The crushed aggregates had a maximum size of $25 \mathrm{~mm}$, and the physical properties are listed in Table 2.

Table 3. Test result of heavy metals extraction for blast furnace slag aggregate.

\begin{tabular}{ccccc}
\hline Test Items & Unit & Value & Remark (Standard) \\
\hline $\mathrm{Pb}$ & & $\mathrm{N} / \mathrm{A}$ & $\leqslant$ & 3 \\
$\mathrm{Cr}$ & $\mathrm{N} / \mathrm{A}$ & $\leqslant$ & 1.5 \\
$\mathrm{Cu}$ & $\mathrm{N} / \mathrm{A}$ & $\leqslant$ & 3 \\
$\mathrm{Cd}$ & $\mathrm{N} / \mathrm{A}$ & $\leqslant$ & 0.3 \\
$\mathrm{As}$ & $\mathrm{Ng} / \mathrm{L}$ & $\mathrm{N} / \mathrm{A}$ & $\leqslant$ & 1.5 \\
$\mathrm{Hg}$ & & $\mathrm{N} / \mathrm{A}$ & $\leqslant$ & 0.005 \\
$\mathrm{CN}^{-}$ & & $\mathrm{N} / \mathrm{A}$ & $\leqslant$ & 1 \\
Organophosphorus & & $\mathrm{N} / \mathrm{A}$ & $\leqslant$ & 0.3 \\
Trichloroethylene & & $\mathrm{N} / \mathrm{A}$ & $\leqslant$ & 0.1 \\
Tetrachloroethylene & & $\leqslant 0.1$ & $\leqslant$ \\
\hline Oil composition & $\%$ & 5 \\
\hline \multicolumn{5}{c}{ N/A: Non-Analysis. }
\end{tabular}

Natural jute fiber is a natural material formed mostly of cellulose. When it is used as a reinforcing agent in cement, unlike artificial fibers it generates little static electricity, reduces fiber aggregation because of its excellent dispersive nature, and increases the adherence of materials because of its roughness. Furthermore, it has been reported that the application of natural jute fibers to the porous vegetation concrete increases the void ratio and the strength [4-6], which was attributed to the hydrophilic nature of jute fiber. Also, this was attributed to stronger hydrogen-bonding between the hydrophilic jute fiber and the cement paste, which increased the bonding strength between the cement paste and the blast furnace aggregate. Figure 2 shows the shape of the jute fiber used herein, and Table 4 lists its physical properties. SB latex was also used in this study. SB latex is a milky semitransparent liquid containing surfactant-coated organic polymer particles (Figure 3). The latex particles form a film during cement hydration. A semi-continuous film forms on the surface of the aggregate and thereby fills the voids. As a result, both the bond and tensile strengths increase. The properties of latex are given in Table 5.

Table 4. Properties of natural jute fibers.

\begin{tabular}{cccccc}
\hline $\begin{array}{c}\text { Elastic Modulus } \\
(\mathbf{G P a})\end{array}$ & $\begin{array}{c}\text { Density } \\
\left(\mathbf{g} / \mathbf{m m}^{\mathbf{3}}\right)\end{array}$ & $\begin{array}{c}\text { Fiber Length } \\
(\mathbf{m m})\end{array}$ & $\begin{array}{c}\text { Fiber Diameter } \\
(\mathbf{m m})\end{array}$ & $\begin{array}{c}\text { Tensile Strength } \\
(\mathbf{M P a})\end{array}$ & Surface \\
\hline 61 & 1.26 & 3 & 0.015 & 510 & Hydrophilic \\
\hline
\end{tabular}




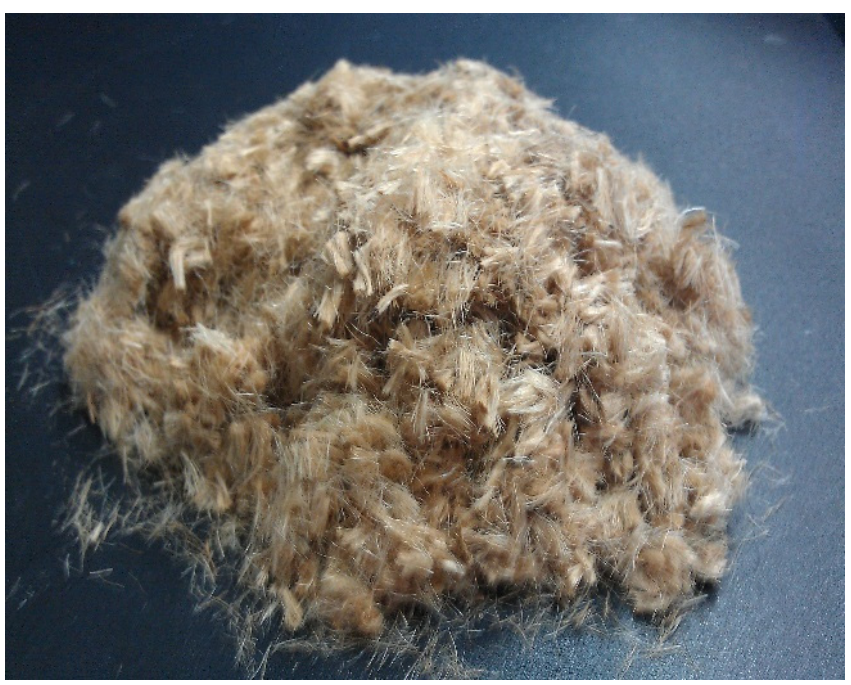

Figure 2. Natural jute fibers.

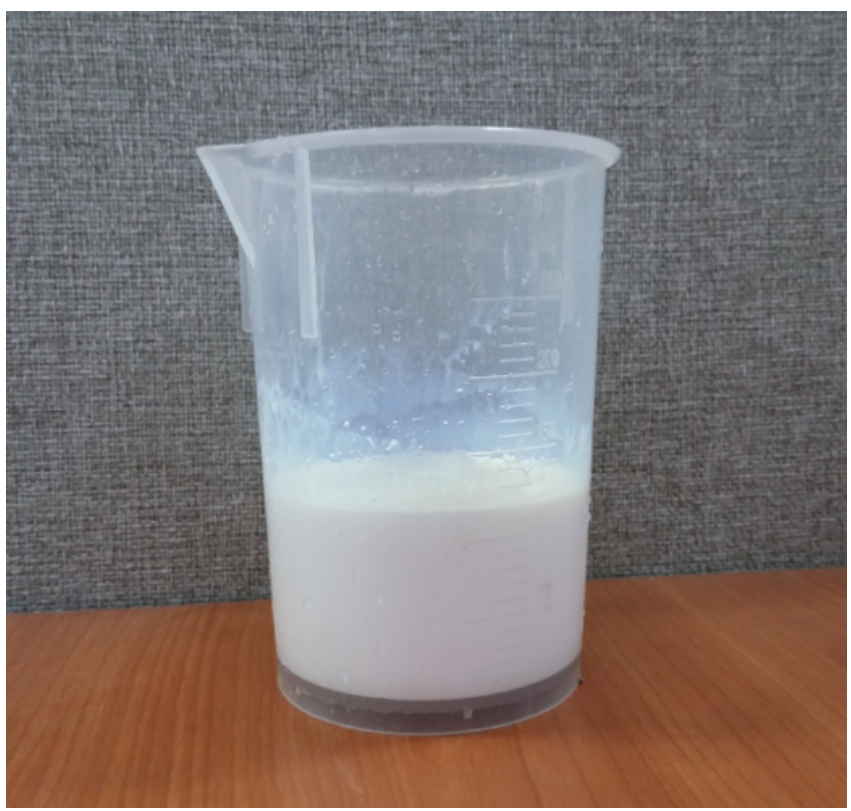

Figure 3. SB latex.

Table 5. Properties of styrene butadiene (SB) latex.

\begin{tabular}{|c|c|c|c|c|c|c|c|}
\hline $\begin{array}{c}\text { Solids } \\
\text { Content (\%) }\end{array}$ & $\begin{array}{c}\text { Styrene } \\
\text { Content (\%) }\end{array}$ & $\begin{array}{l}\text { Butadiene } \\
\text { Content (\%) }\end{array}$ & $\mathrm{pH}$ & $\begin{array}{l}\text { Density } \\
\left(\mathrm{g} / \mathrm{mm}^{3}\right)\end{array}$ & $\begin{array}{l}\text { Surface Tension } \\
\quad(\text { dyne/cm) }\end{array}$ & $\begin{array}{l}\text { Particle } \\
\text { Size (Å) }\end{array}$ & $\begin{array}{l}\text { Viscosity } \\
\text { (cps) }\end{array}$ \\
\hline 49 & $34 \pm 1.5$ & $66 \pm 1.5$ & 11.0 & 1.02 & 30.57 & 1700 & 42 \\
\hline
\end{tabular}

\subsection{Mix Proportions}

The default mixing ratio was determined from a literature survey and analysis of previous studies on vegetation concrete blocks. The substitution ratio of blast furnace slag aggregate was $40 \%$. Also, jute fibers were added $0.1 \%(\mathrm{Vol}, \%)$ and the latex was added in a quantity of about $0.02 \%$ of the blast slag cement weight. The mixing ratio was determined based on the addition of latex and natural jute fiber, as listed in Table 6. The main purpose of this study is to develop porous vegetation concrete with structural stability, in which plant growth was facilitated. The EL245 environmental declaration for water-permeable concrete products, issued by the Korean Ministry of Environment, lists the following 
standards for porous vegetation concrete: a compressive strength of $\geqslant 12 \mathrm{MPa}$, void ratio of $\geqslant 25 \%$ and residual compressive strength following repeated freeze-thaw cycles of $\geqslant 80 \%$ [20]. This study aimed to comply with these standards.

Table 6. Mixture design of porous vegetation concrete.

\begin{tabular}{ccccccc}
\hline & \multicolumn{5}{c}{ Unit Weight $\mathbf{( k g / \mathbf { m } ^ { 3 } )}$} \\
\cline { 2 - 5 } Mix Code & Water & $\begin{array}{c}\text { Blast Furnace } \\
\text { Slag Cement }\end{array}$ & \multicolumn{2}{c}{ Aggregate } & \multirow{2}{*}{ Fiber } & Latex \\
\cline { 4 - 6 } & & $\mathbf{2 5} \mathbf{~ m m}$ & Blast Furnace Slag & & \\
\hline Plain & 79 & 306 & 1412 & 0 & 0 & 0 \\
BFS & 79 & 306 & 847 & 565 & 0 & 0 \\
BFS-fiber & 79 & 306 & 847 & 565 & 1.2 & 0 \\
BFS-latex & 75 & 306 & 847 & 565 & 0 & 6.2 \\
\hline
\end{tabular}

\subsection{Test Methods}

\subsubsection{Void Ratio}

Porous vegetation concrete has pores that enable plant growth. The void ratio is a particularly important factor: a low void ratio typically leads to high strength, but does not facilitate plant growth; however, a high void ratio may lead to low strength. Therefore, it is critically important to control the void ratio. Here we investigated how the void ratio of porous vegetation concrete is affected by the addition of blast furnace slag aggregate, natural jute fibers and latex. This study investigated the void ratio using conical specimens that were $100 \mathrm{~mm}$ in diameter and $200 \mathrm{~mm}$ in height using the volumetric method provided by the Eco-Concrete Research Commission of the Japan Concrete Industrial Association. The void ratio is given by

$$
\mathrm{P}_{\mathrm{a}}=1-\frac{\mathrm{W}_{2}-\mathrm{W}_{1}}{\mathrm{~V}} \times 100
$$

where $W_{1}$ and $W_{2}$ are the underwater and oven-dried weights of the specimen after 28 days, respectively, and $V$ is the volume of the specimen.

To characterize the void ratio, the conical specimens were cured for $24 \mathrm{~h}$ following production at $23 \pm 2{ }^{\circ} \mathrm{C}$ and $58 \%$ relative humidity. The specimens were prepared such that the pores were saturated with water as much as possible (Figure 4a). After water curing for 1 day before the test, the specimens were measured based on their dry weight after measuring the weight of the water (Figure 4b). The void ratio test was performed on the six specimens from each mix proportion.

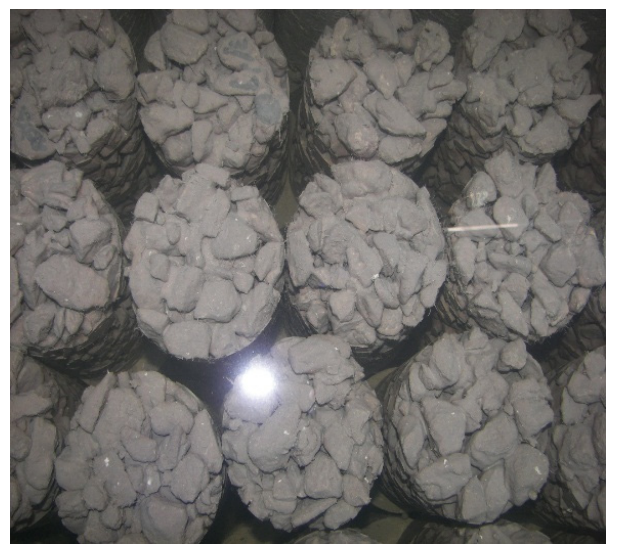

(a)

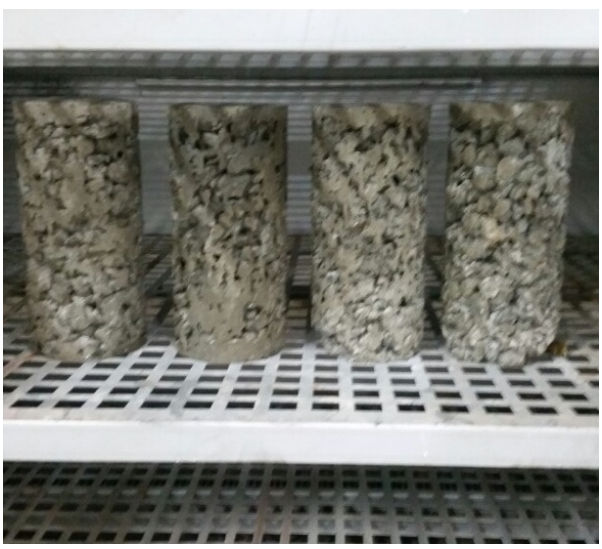

(b)

Figure 4. Void ration test specimens. (a) Wet conditions; (b) Dry conditions. 


\subsubsection{Compressive Strength}

The compressive strength was characterized according to ASTM C39/C39M-15a [21]. Specimens of $100 \mathrm{~mm}$ in diameter and $200 \mathrm{~mm}$ in height were cured for $24 \mathrm{~h}$ at $23 \pm 2{ }^{\circ} \mathrm{C}$ and $58 \%$ relative humidity. The samples were removed from the mold and cured in water for 28 days at $23 \pm 2{ }^{\circ} \mathrm{C}$. The compressive strength test was performed on the six specimens from each mix proportion. Figure 5 shows the compressive strength test.

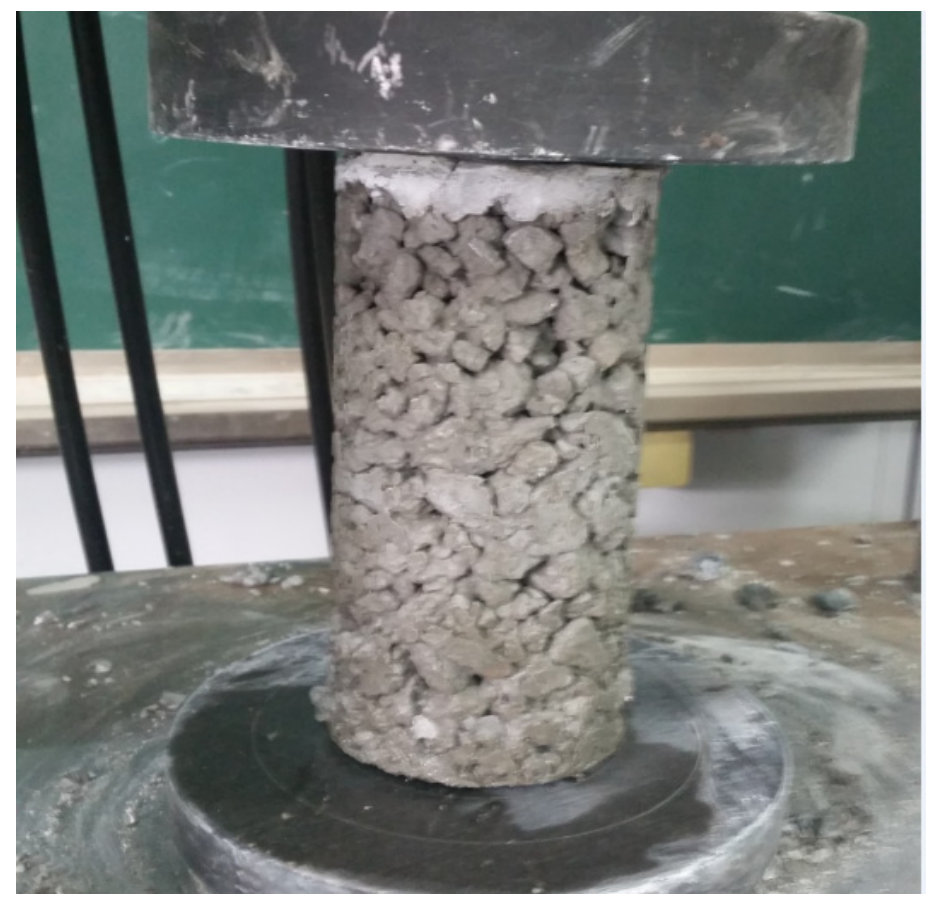

Figure 5. Compressive strength test set-up.

\subsubsection{Freeze-Thaw Cycles}

Repeated freezing and thawing tests were carried out according to the ASTM C666/C666M-15 standard [22]. The freeze-thaw experiment was conducted by cooling the sample from $4{ }^{\circ} \mathrm{C}$ to -18 ${ }^{\circ} \mathrm{C}(4 \mathrm{~h})$ then raising the temperature to $4{ }^{\circ} \mathrm{C}(4 \mathrm{~h})$, for 100 cycles. A compressive strength test was then conducted to measure the residual compressive strength. The compressive strength test was performed on the six specimens from each mix proportions.

\subsubsection{Plant Growth}

With porous vegetation concrete, it is important that seeds can sprout and that plants adhere to the concrete. To analyze the vegetation capacity of the concrete, comparative tests were carried out using $200 \mathrm{~mm}$ (width) $\times 200 \mathrm{~mm}$ (length) $\times 100 \mathrm{~mm}$ (height) cubic specimens [6,9,23], as shown in Figure 6. To analyze of vegetation capacity, sprouting and the length of perennial ryegrass shoots (which thrive in cold and wet environments) were monitored. Then, $20 \mathrm{~g}$ of ryegrass seeds were sowed on each block while it was submerged underwater, as shown in Figure 7. 


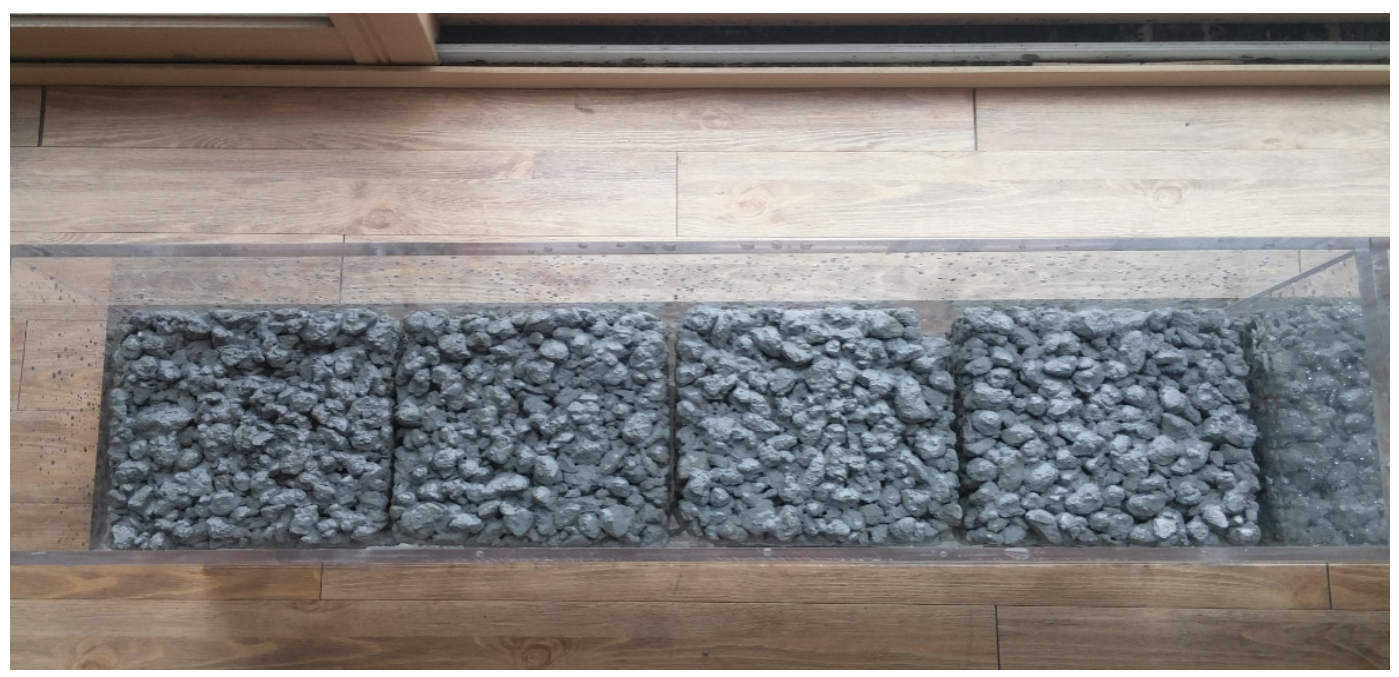

Figure 6. Installation of porous vegetation concrete.

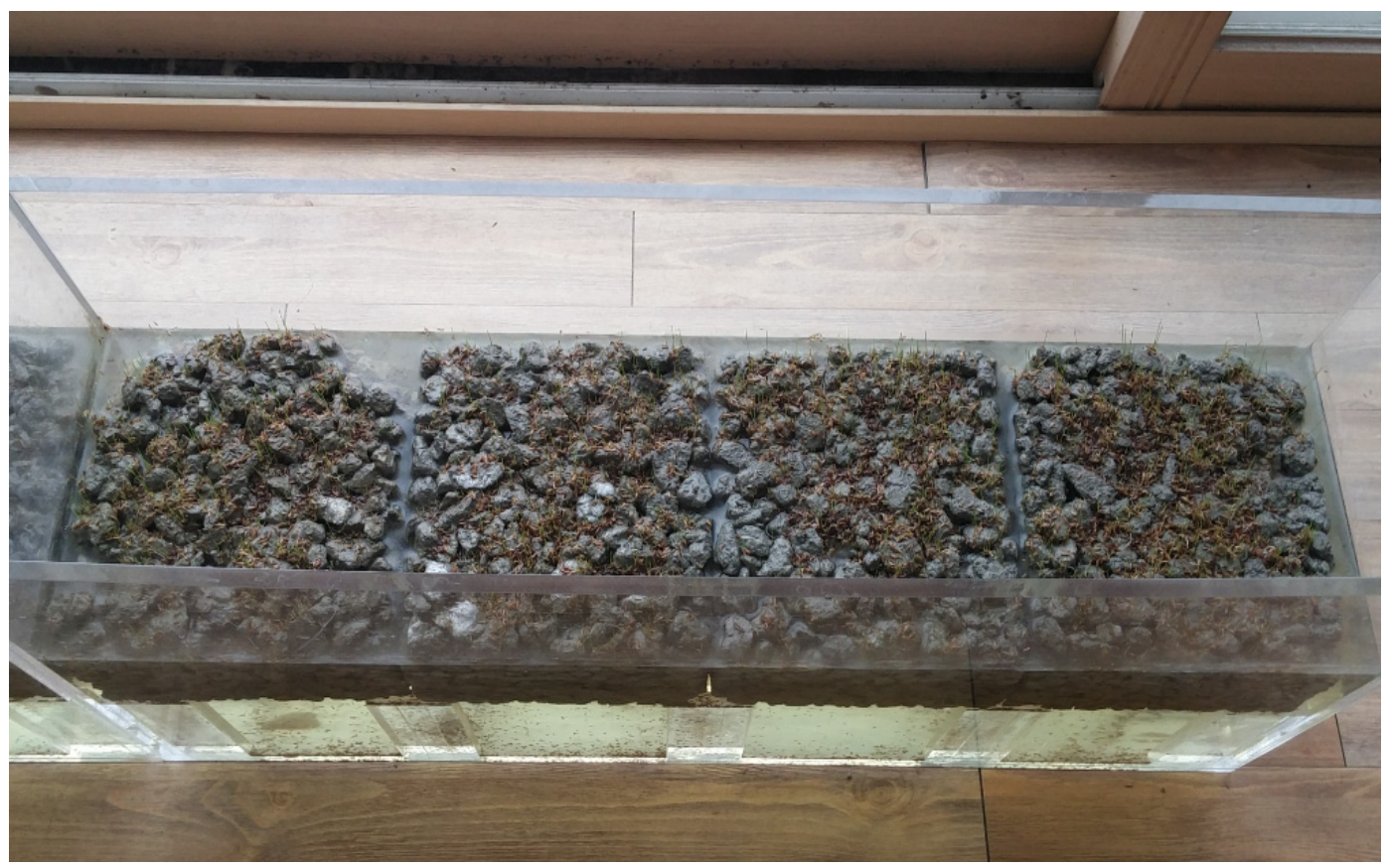

Figure 7. Photo of seeding completed.

\subsubsection{Water Purification}

The $200 \mathrm{~mm} \times 200 \mathrm{~mm} \times 100 \mathrm{~mm}$ specimens that had been used for the vegetation analyses were subsequently used in the water purification analysis. This study analyzed the water quality before and after vegetation using a standard water pollution process test [24]. An acrylic port was formed, and the residence time was $10 \mathrm{~min}$. Water with known concentrations of dissolved ammonia-nitrogen, phosphorate-phosphorus, total nitrogen and total phosphorus was produced using reagents in the same manner as with the blast furnace slag aggregate water purification test. Figure 8 shows a photograph before vegetation, and Figure 9 shows a photograph after vegetation. 


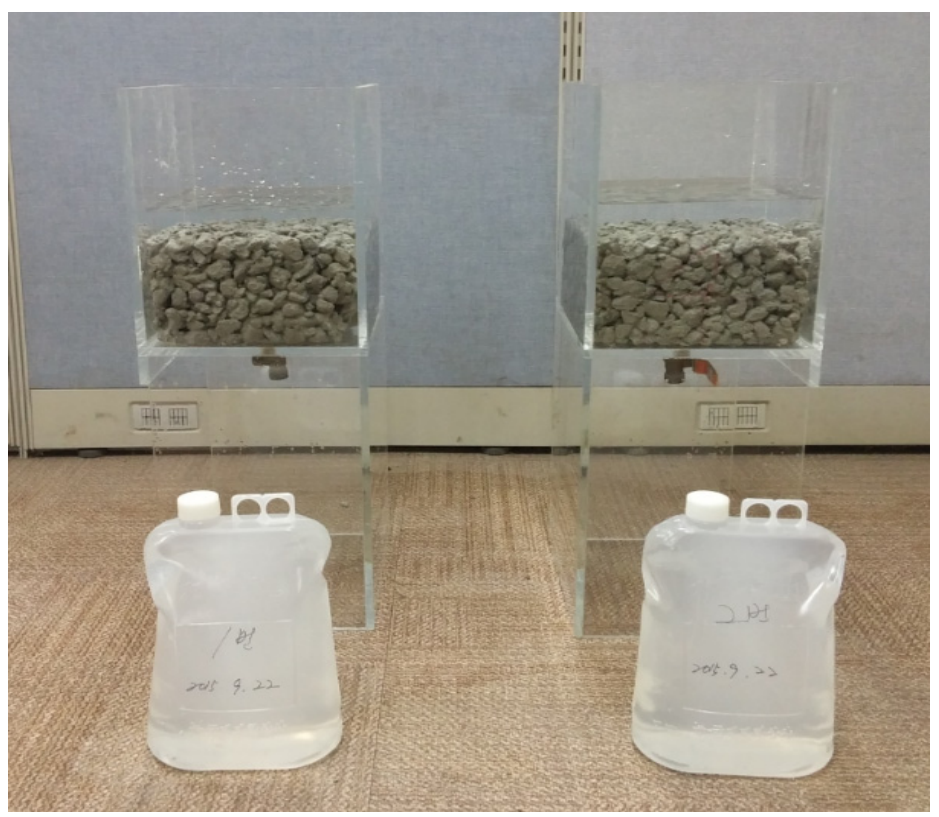

Figure 8. Sampling before plant.

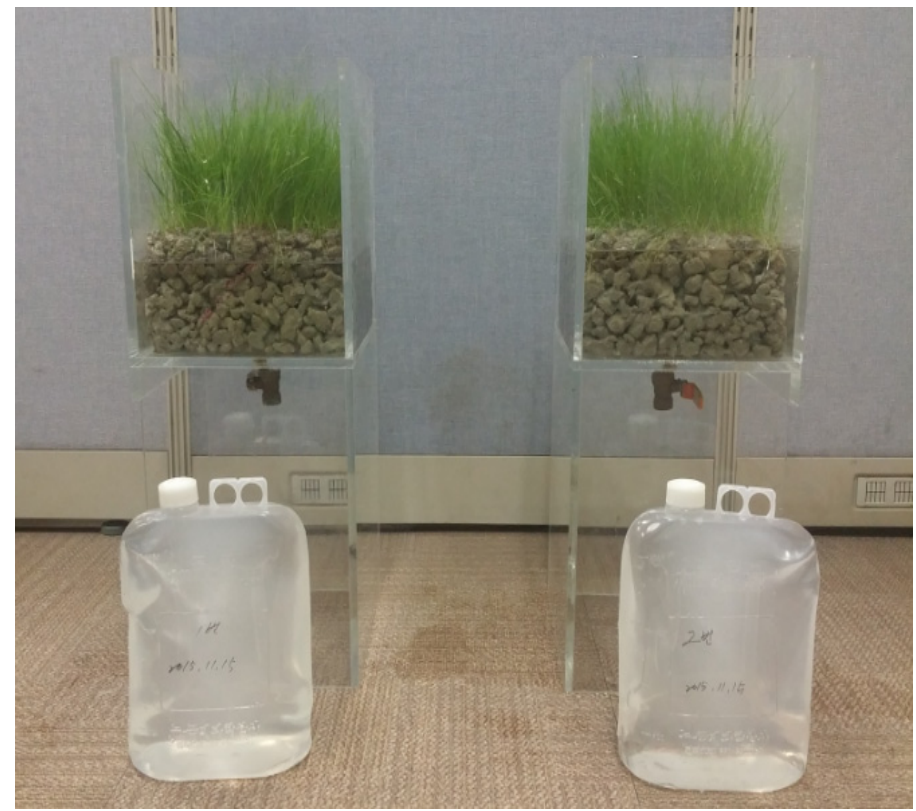

Figure 9. Sampling after plant.

\section{Results and Discussion}

\subsection{Void Ratio}

Figure 10 shows the void ratio for the four different mixes; i.e., the default mix, as well as porous vegetation concrete with added blast furnace slag aggregate, with natural jute fibers and with latex. The inclusion of blast furnace slag aggregate resulted in a larger void ratio than with crushed aggregate. The larger void ratio is attributed to the blast furnace slag aggregates being more porous than crushed aggregates. The mix with natural jute fiber exhibited the largest void ratio. The specimen with added latex also exhibited an increased void ratio. The target void ratio of $\geqslant 25 \%$ was satisfied by all mixtures except plain. Therefore, this study concludes that it is necessary to add natural jute fiber or latex or blast furnace slag aggregates to satisfy the target void ratio. 


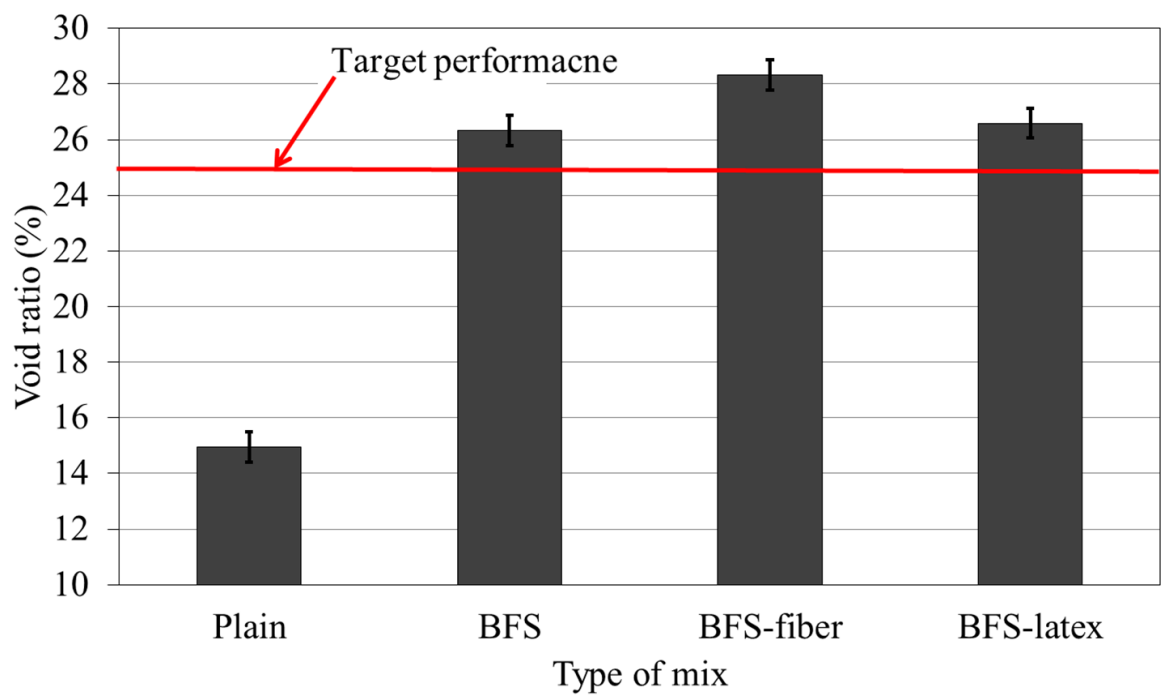

Figure 10. Void ratio result of porous vegetation concrete.

\subsection{Compressive Strength}

Figure 11 shows the results of the compressive strength tests. The compressive strength of the porous vegetation concrete increased when blast furnace slag aggregate was used. This is attributed to the similar pozolanic reaction of the blast furnace slag aggregate. In previous research, blast furnace slag aggregate have been shown to have the tendancy to increase strength of concrete [25]. The addition of natural jute fiber resulted in a decrease in the compressive strength. Generally, the addition of jute fiber improves the tensile and flexural strengths of porous vegetation concrete, rather than the compressive strength. This is because the fiber enhances the bond strength between materials when concrete is subjected to flexural or tensile loading [26,27]. Also, this is attributed to the low slump of the relatively dry mixture, as the porous concrete may have insufficient fluidity so that the fibers partake in balling [11]. Therefore, the compressive strength of the porous vegetation concrete is decreased [11]. The addition of latex increased the compressive strength of the porous vegetation concrete, which is attributed to an increase in the early fluidity, promoting the coating of the binder around the aggregates and hence the adherence of the aggregates. The target compressive strength of $\geqslant 12 \mathrm{MPa}$ was satisfied by all mixtures except those containing natural jute fibers.

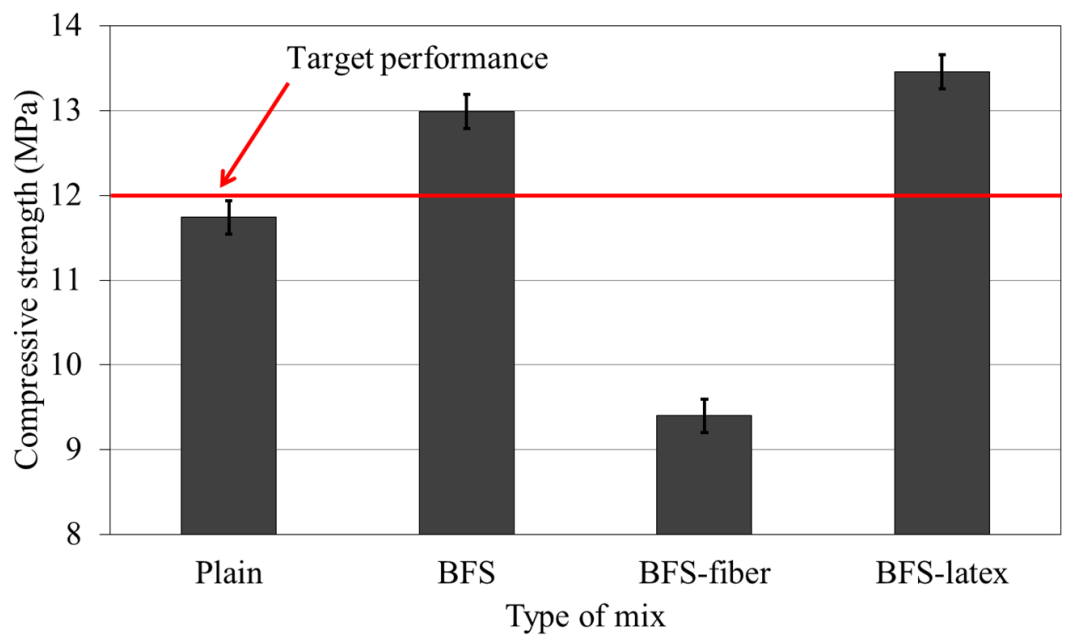

Figure 11. Compressive strength result of porous vegetation concrete. 


\subsection{Repeated Freezing-Thawing Cycles}

Following 28 days of curing, cyclic freeze-thaw tests were carried out (100 cycles), and the compressive strength was determined. The compressive strength decreased following the freeze-thaw cycles for all mixes, as shown in Figure 12. The decrease was particularly large for the porous concretes with a large void ratio. However, the addition of natural jute fiber suppressed the generation and growth of cracks between aggregates following repeated freeze-thaw cycles. The hydrophilic nature of jute fiber improved the water purification properties and increased the adherence at the surface due to increased hydrogen bonding; it also appeared to increase the freeze-thaw resistance. The freeze-thaw resistance tests with added latex exhibited a decreased compressive strength following the repeated freeze-thaw cycles. The use of latex increased the early fluidity of the porous concrete to promote coating of the binder onto the surface of the aggregates, thereby strengthening this interface and improving the adherence of aggregates into the matrix. Because of this, the decrease in the compressive strength following the freeze-thaw tests was relatively small. Following 100 freeze-thaw cycles, the target of $\geqslant 80 \%$ residual compressive strength was achieved by all mixtures containing blast furnace slag, natural jute fiber and latex, but not by the default mixture. Therefore, to provide freeze-thaw resistance, we should consider the use of blast furnace slag aggregate, natural jute fiber and latex.

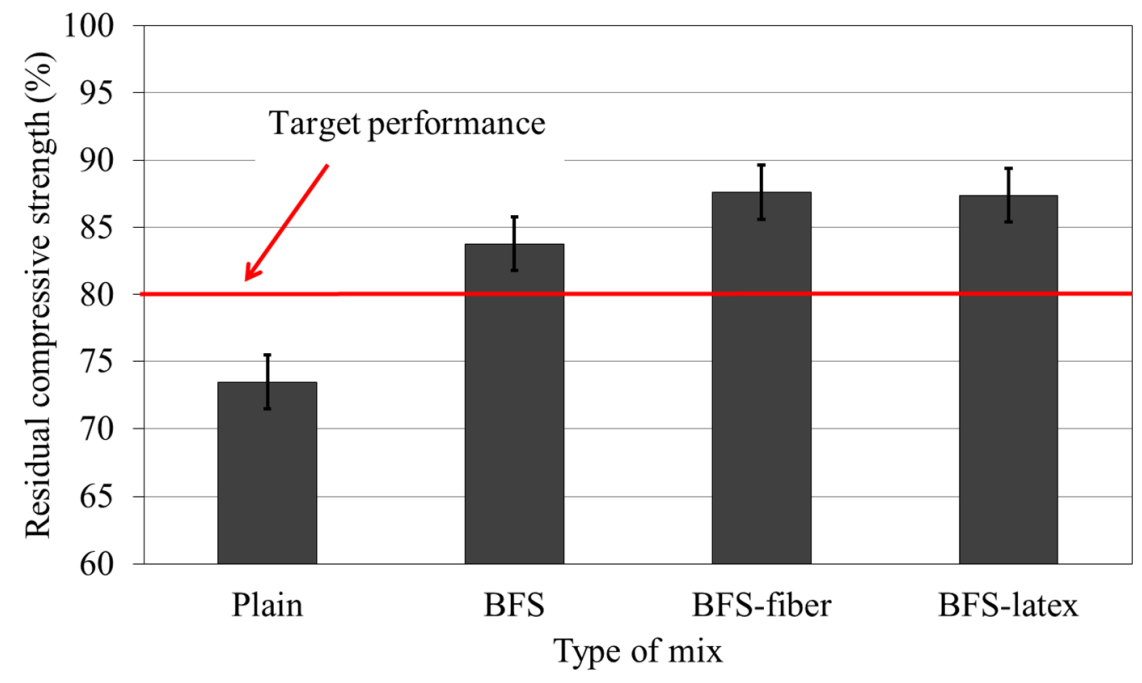

Figure 12. Repeated freezing and thawing test results result of porous vegetation concrete.

\subsection{Plant Growth}

Figure 13 shows the temperature and relative humidity as a function of time in the test chamber that was used to monitor vegetation. The average temperature was $25.4^{\circ} \mathrm{C}$ and the average relative humidity was $48.8 \%$. The daily maximum temperature was $30^{\circ} \mathrm{C}$, and the daily minimum temperature was $24^{\circ} \mathrm{C}$. Two days after sowing, seeds began to sprout, as shown in Figure 14. Figure 15 shows the results of vegetation monitoring, and Figure 16 shows photographs of the grass shoots for the different samples at various times. On the third day, the length of the grass shoots was $12-13 \mathrm{~mm}$. After 9 days, the length began to differ among the specimens. After 11 days, the mixture with latex exhibited the longest grass shoots $(91 \mathrm{~mm})$, while the default mixture had the shortest shoots $(80 \mathrm{~mm})$. After 25 days, the mixture with latex exhibited the longest grass $(152 \mathrm{~mm})$, which was $28 \mathrm{~mm}$ longer than that of the default mixture. The mixtures with blast furnace slag aggregate and natural jute fiber exhibited similar length grass shoots, which were approximately $10 \mathrm{~mm}$ longer than those of the default mixture. When blast furnace slag aggregate was used, the vegetation growth was more active. Furthermore, the use of latex promoted plant growth. This is attributed to the latex forming a coating to prevent toxic components from leaching out of the cement. 


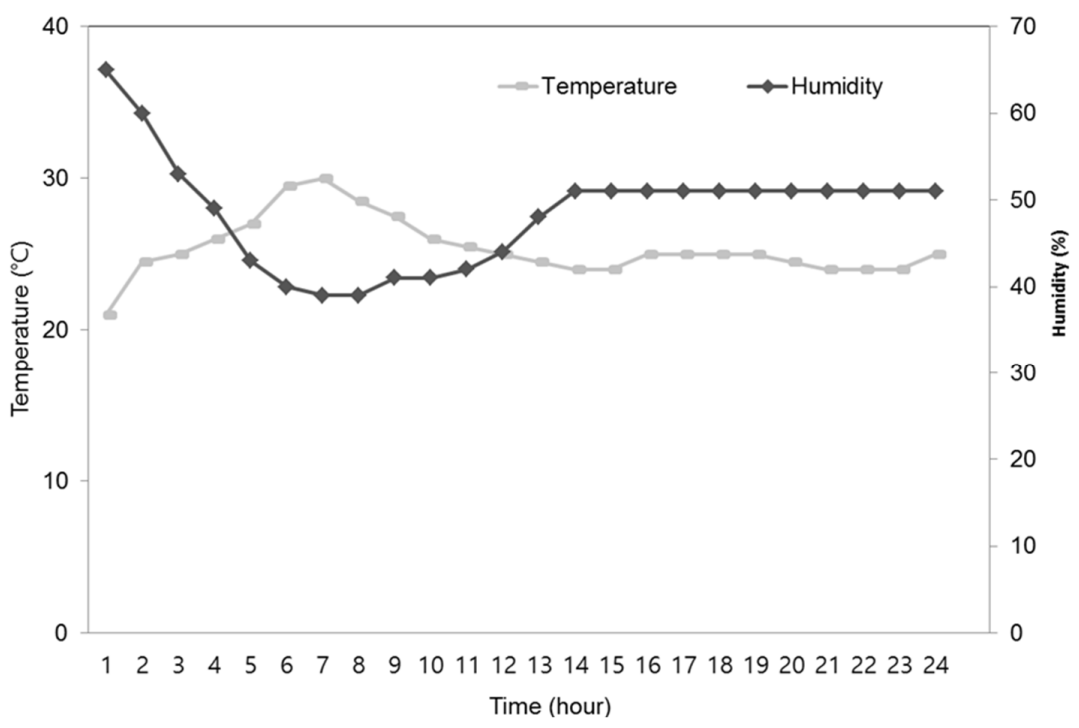

Figure 13. Graph of temperature and humidity.

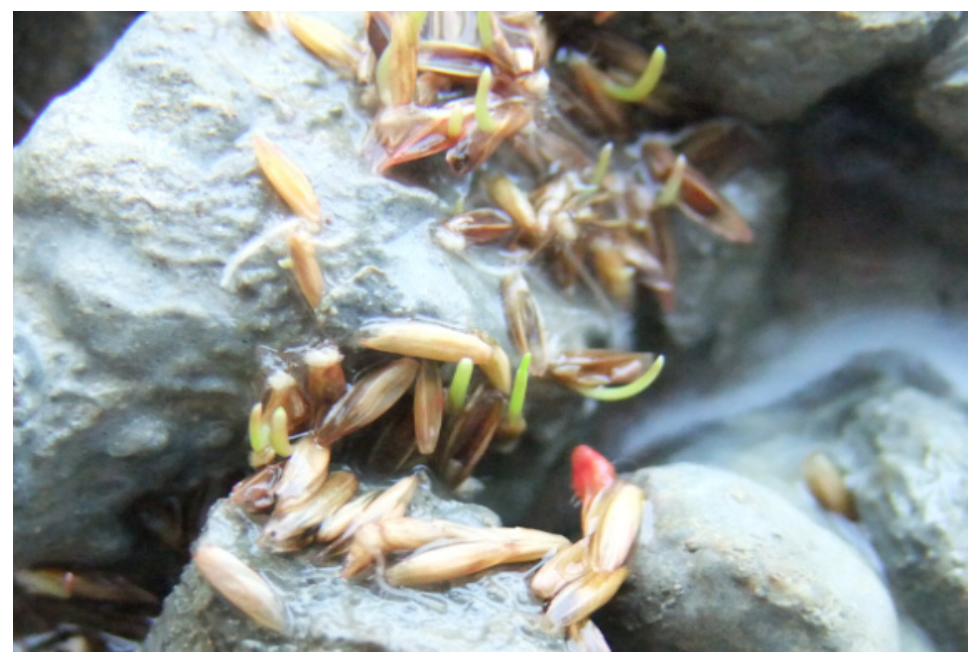

Figure 14. Photo of plants germination on porous vegetation concrete.

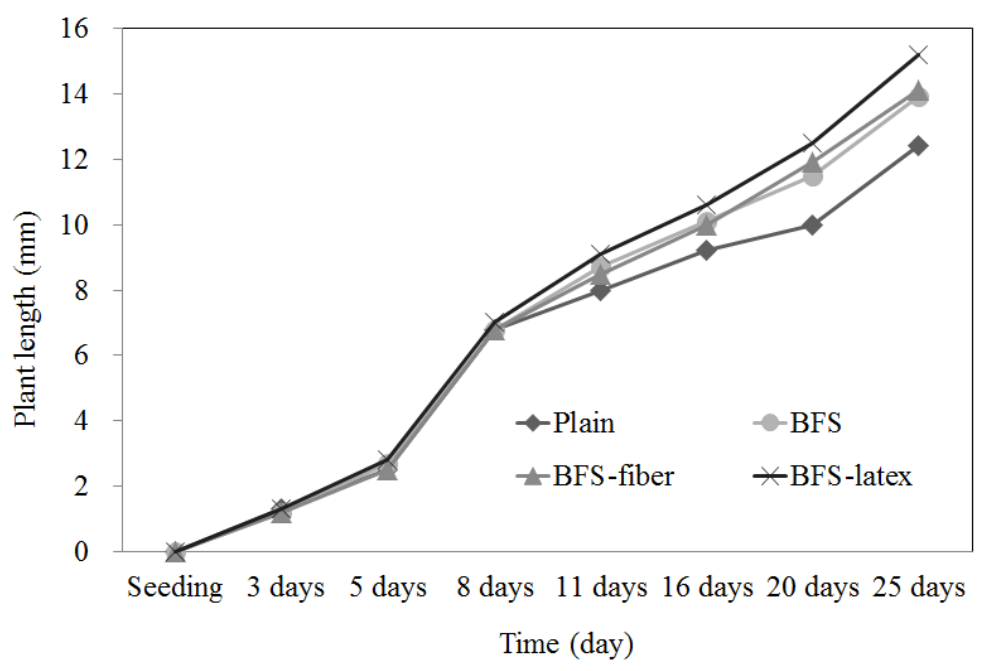

Figure 15. Graph of plants growth in laboratory. 


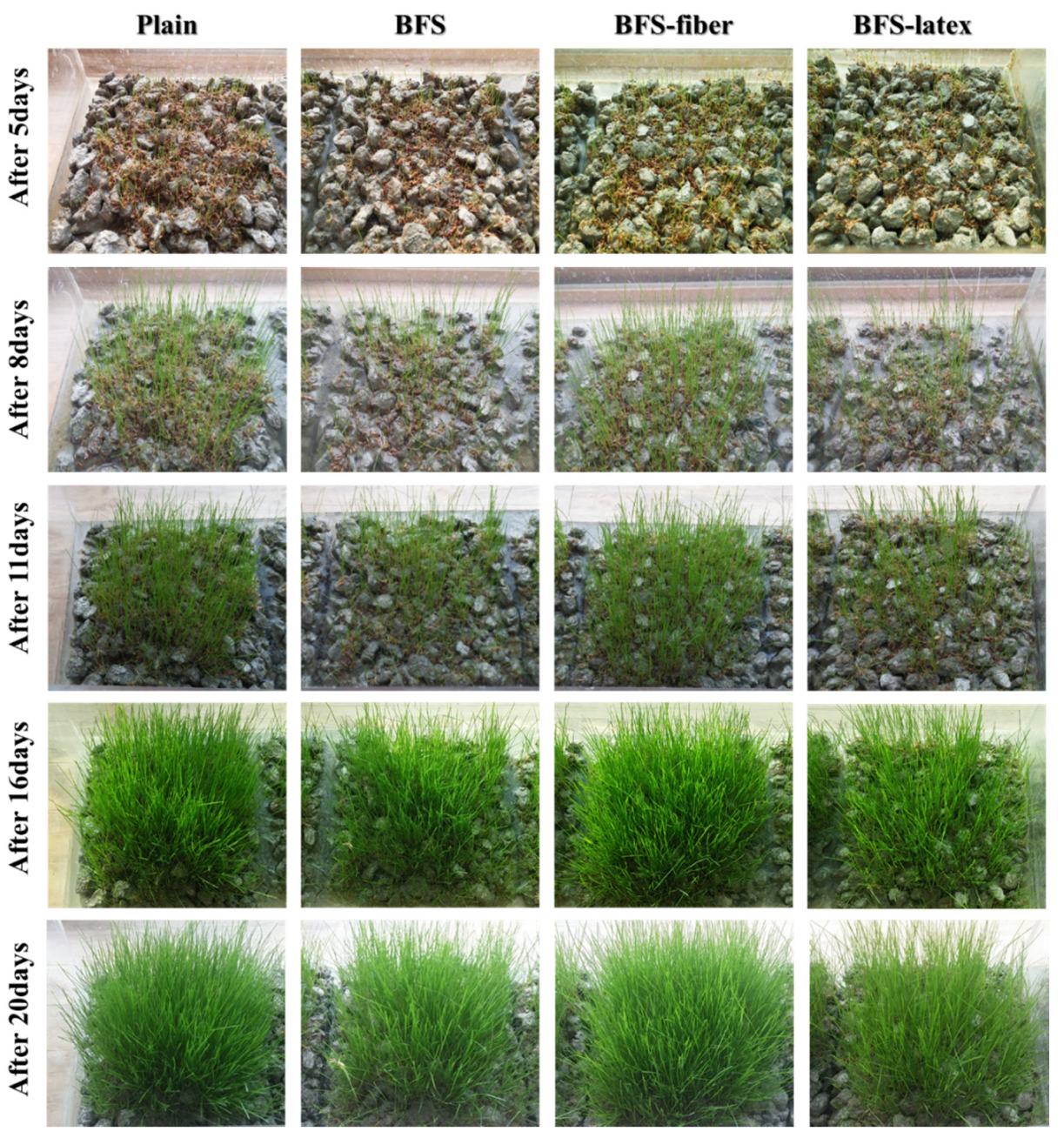

Figure 16. Photo of plants length research in laboratory.

\subsection{Water Purification}

Figures 17-20 show the results of the water purification tests. Following vegetation, the density of ammonia-nitrogen in the inflow water was $19.89 \mathrm{mg} / \mathrm{L}$ and that in the outflow water was in the range $17.73-18.42 \mathrm{mg} / \mathrm{L}$, which corresponds to a treatment efficiency of $7.38 \%-10.85 \%$. Following vegetation, the density of total nitrogen in the inflow water was $20.26 \mathrm{mg} / \mathrm{L}$, and that in the outflow water was in the range $18.36-19.02 \mathrm{mg} / \mathrm{L}$, which corresponds to a treatment efficiency of $6.14 \%-9.40 \%$. The treatment efficiencies before and after vegetation were similar, and did not differ significantly among the mixtures. Following vegetation, the density of phosphorate-phosphorus in the inflow water was $1.96 \mathrm{mg} / \mathrm{L}$, and that in the outflow water was in the range $1.74-1.79 \mathrm{mg} / \mathrm{L}$, which corresponds to a treatment efficiency of $9.57 \%-11.24 \%$. The phosphorate-phosphorus treatment efficiency before vegetation was in the range $18.00 \%-31.00 \%$, which is significantly greater than that after vegetation. Following vegetation, the density of total phosphorus in the inflow water was $2.34 \mathrm{mg} / \mathrm{L}$, and that in the outflow water was in the range $2.06-2.26 \mathrm{mg} / \mathrm{L}$, which corresponds to a treatment efficiency of $6.36 \%-11.78 \%$. Prior to vegetation, the total phosphorus treatment efficiency was in the range $12.66 \%-24.45 \%$, which is significantly greater than that after vegetation. It appears that the residence time (10 $\mathrm{min}$ ) was too short to obtain a significant water purification effect due to the vegetation. Furthermore, as the phosphorus materials (which are usually removed by precipitation and water purification) accumulated in the specimen during the tests without vegetation, the effects of vegetation on water purification were limited. Furthermore, we cannot exclude the possibility that residual materials were used as nutrient sources following sprouting of the seeds. The difference in treatment efficiency among the mixtures 
was not significant. The porous vegetation concrete formed using the blast furnace slag aggregates exhibited the greatest water purification effect for phosphorate-phosphorus and total phosphorus.

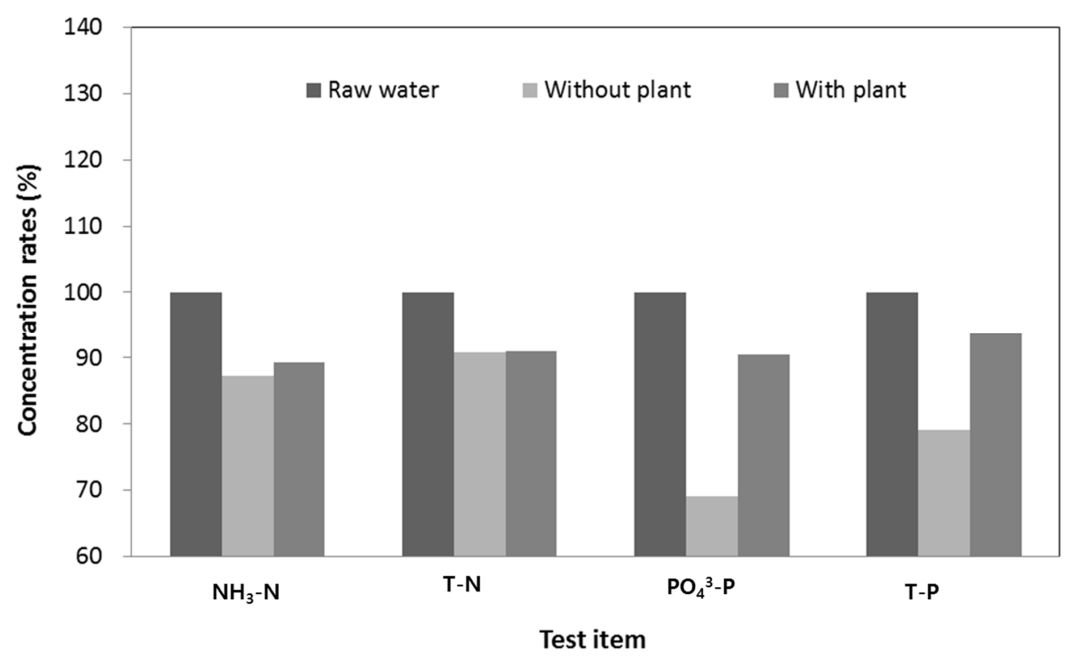

Figure 17. Ion adsorption test results of Plain mix.

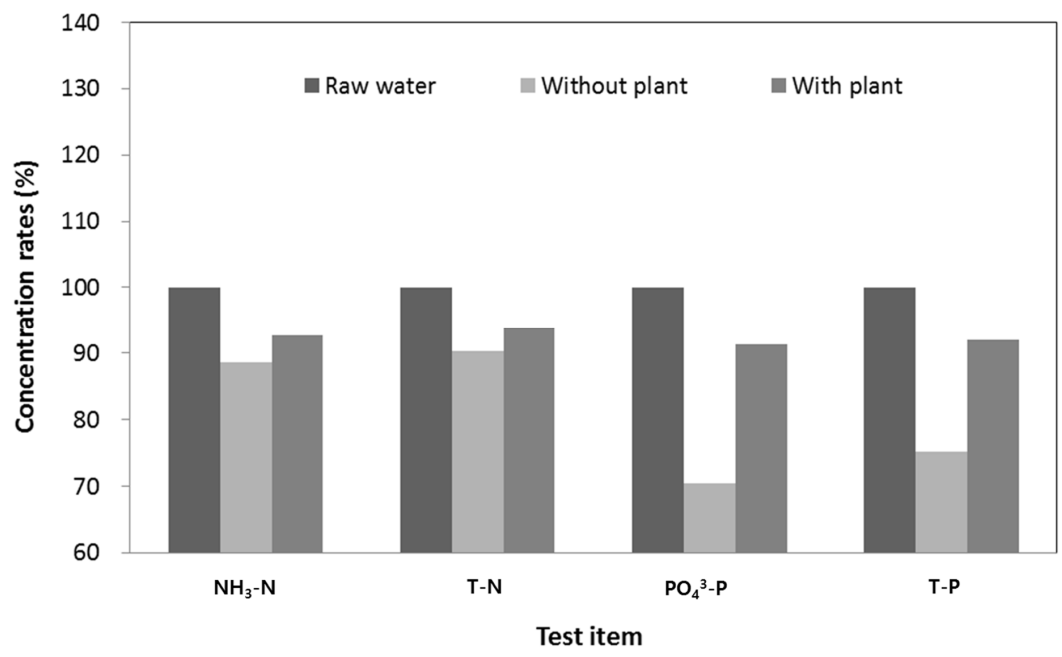

Figure 18. Ion adsorption test results of BFS mix.

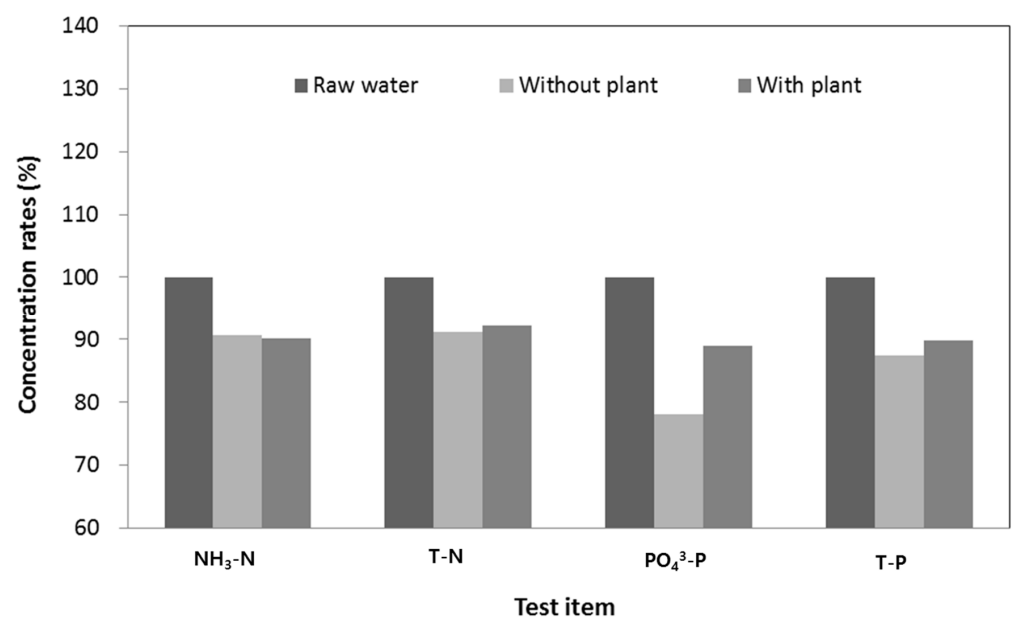

Figure 19. Ion adsorption test results of BFS-fiber mix. 


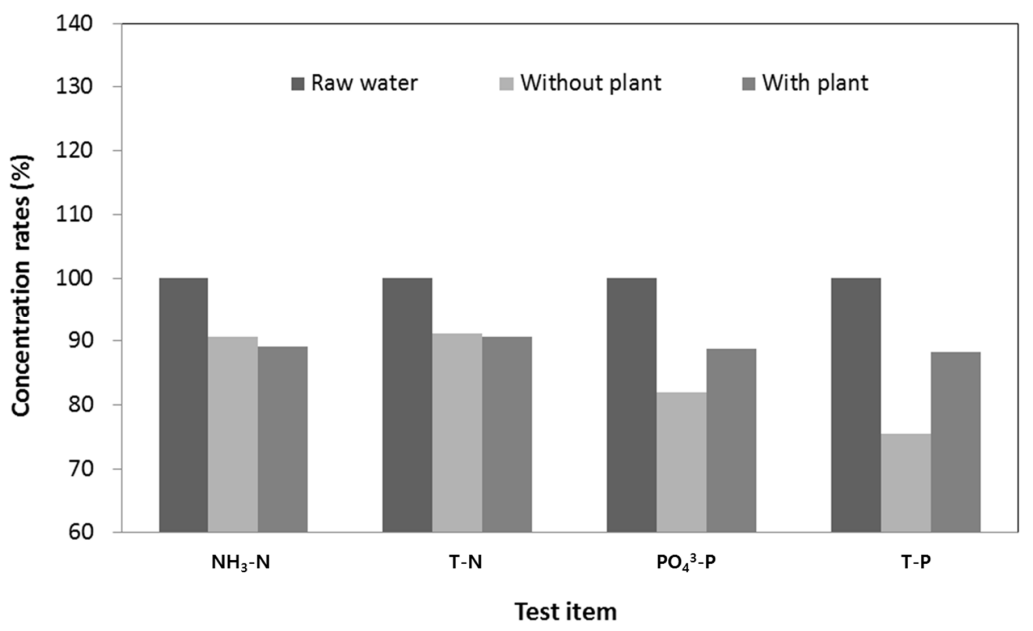

Figure 20. Ion adsorption test results of BFS-latex mix.

\subsection{Optimum Mix}

The porous vegetation concrete with latex exhibited increased compressive strength, a larger void ratio and improved freeze-thaw resistance compared with the default mix. With almost all the mixtures that included latex, the target specifications were satisfied. In terms of the vegetation capacity in particular, the use of latex provided highly favorable results. Therefore, considering the mechanical properties of porous vegetation concrete, as well as the freeze-thaw resistance, vegetation capacity and water purification capacity, the mix with latex and blast furnace slag aggregate was selected as the optimum mixture (see Table 7). The compressive strength of the resulting optimum mixture was $13.46 \mathrm{MPa}$, the void ratio was $27.41 \%$, and the residual compressive strength following 100 freeze-thaw cycles was $87.38 \%$.

Table 7. Optimum mixture design.

\begin{tabular}{|c|c|c|c|c|}
\hline \multicolumn{5}{|c|}{ Unit Weight $\left(\mathrm{kg} / \mathrm{m}^{3}\right)$} \\
\hline \multirow{2}{*}{ Water } & \multirow{2}{*}{ Blast furnace slag cement } & \multicolumn{2}{|c|}{ Aggregate } & \multirow{2}{*}{ Latex } \\
\hline & & $25 \mathrm{~mm}$ & Blast furnace slag & \\
\hline 75 & 306 & 847 & 565 & 6.2 \\
\hline
\end{tabular}

\section{Conclusions}

The purpose of this study was to evaluate the performance of the porous vegetation concrete. Target performance metrics of the porous vegetation concrete were a compressive strength of $\geqslant 12 \mathrm{MPa}$, a void ratio of $\geqslant 25 \%$, and residual compressive strength of $\geqslant 80 \%$ following 100 freeze-thaw cycles. Vegetation capacity tests and water purification tests were carried out to identify the optimal mixing ratio. The results of this study can be summarized as follows.

(1) Characterization of the physical and mechanical properties of the porous vegetation concrete showed that mixtures that contained latex exhibited favorable compressive strength, void ratio and freeze-thaw resistance.

(2) Vegetation growth tests showed that plant growth was more active when blast furnace slag aggregate was used. The use of latex was also found to promote plant growth, which is attributed to the latex forming a film coating that prevents toxic compounds from being leached from the cement. 
(3) A water purification test revealed no clear differences among the mixtures. Comparisons of mixes with and without vegetation showed greater water purification effects on phosphorate-phosphorus and total phosphorus with vegetation.

(4) The mix containing blast furnace slag aggregate and latex satisfied all of the target performance metrics; i.e., compressive strength of $\geqslant 12 \mathrm{MPa}$, a void ratio of $\geqslant 25 \%$, and residual compressive strength following 100 freeze-thaw cycles of $80 \%$, as well as excellent plant growth and water purification properties. For these reasons, this mix was identified as the optimal mixture.

Acknowledgments: This research was supported by the basic science research program through the national research foundation of Korea (NRF) founded by ministry of education (NRF-2013R1A1A4A01011776). Also, this research was supported by a grant (code-14TBIP-C073993-01-000000) from Technology Business Innovation Program (TBIP) funded by Ministry of Land, Infrastructure and Transport of Korean government.

Author Contributions: Hwang-Hee Kim conceived and designed the experiments; Chan-Gi Park analyzed the data and wrote the paper. All authors have read and approved the final manuscript.

Conflicts of Interest: The authors declare no conflict of interest.

\section{References}

1. Kim, H.H.; Kang, S.M.; Park, J.S.; Park, S.W.; Jeon, J.H.; Lee, J.H.; Cha, S.S.; Park, C.G. Performance evaluation of porous hwang-toh concrete using blast furnace slag cement. J. KSAE 2010, 52, 9-17. [CrossRef]

2. Kim, D.H.; Kim, C.S.; Park, C.G. Physical and mechanical properties of non-cement porous concrete with alkali-activator contents. J. KSAE 2013, 52, 9-17. [CrossRef]

3. Kim, H.H.; Kim, C.S.; Jeon, J.H.; Park, C.G. Physical, mechanical properties and freezing and thawing resistance of non-cement porous vegetation concrete using non-sintering inorganic binder. J. KSAE 2014, 56, 37-44. [CrossRef]

4. Lee, J.Y.; Park, J.S.; Park, C.G. Effect of reinforcing fiber on mechanical properties and chemical resistance of porous concrete with hwang-toh. J. KSCE 2011, 55, 65-72.

5. Oh, R.O.; Kim, C.S.; Kim, H.H.; Jeon, J.H.; Kwon, W.S.; Park, C.G. Physical, mechanical and temperature properties of fiber reinforced porous green roof hwang-toh concrete. J. KSAE 2013, 55, 65-72.

6. Oh, R.O.; Cha, S.S.; Park, S.Y.; Lee, H.J.; Park, S.W.; Park, C.G. Mechanical properties and water purification characteristics of natural jute fiber-reinforced non-cement alkali-activated porous vegetation blocks. Paddy Water Environ. 2014, 12, S149-S156. [CrossRef]

7. Park, S.B.; Lee, B.C.; Kim, J.H.; Yun, D.Y. Planting-ability valuation of porous concrete using industrial by-products. J. KCI 2002, 14, 623-629.

8. Park, S.B.; Lim, C.D. Concrete for planting. Mag. KCI 2000, 12, 38-42.

9. Sung, C.Y.; Kim, Y.I. Experimental study on development of plantable concrete block using rice straw ash and application for inclined plane. J. KSAE 2003, 45, 107-114.

10. Youn, J.N.; Sung, C.Y.; Kim, Y.I. Physical and mechanical properties of porous concrete using waste activated carbon. J. KSAE 2009, 51, 21-27. [CrossRef]

11. Kim, H.H.; Kim, C.S.; Jeon, J.H.; Park, C.G. Effects on the Physical and Mechanical Properties of Porous Concrete for Plant Growth of Blast Furnace Slag, Natural Jute Fiber, and Styrene Butadiene Latex Using a Dry Mixing Manufacturing Process. Materials 2016, 9, 84. [CrossRef]

12. Yang, K.H.; Song, J.K.; Lee, K.H. A Stress-Strain Relationship of Alkali-Activated Slag Concrete. J. KCI 2011, 23, 765-772. [CrossRef]

13. Han, S.H.; Yong, M.J. The future of concrete admixture industry for low carbon, green growth. Mag. KCI 2009, 21, 41-43.

14. Kim, T.H.; Tae, S.H. A Study on the Development of an Evaluation System of $\mathrm{CO}_{2}$ Emission in the Production of Concrete. J. KCI 2010, 22, 787-796.

15. Mun, H.Y.; Jung, S.J.; Lim, N.K. Blast furnace slag aggregate. Mag. KCI 1997, 9, 18-22.

16. Park, S.B.; Lee, B.J.; Lee, J.; Jang, Y.I. A study on the seawater purification characteristics of water-permeable concrete using recycled aggregate. Resour. Conserv. Recycl. 2010, 54, 658-665. [CrossRef]

17. Song, W.-J.; Fu, H.-Y.; Wang, G.-Y. Study on a kind of ecoconcrete retaining wall's block with water purification function. Procedia Eng. 2012, 28, 182-189. 
18. Land \& Housing Institute. Development of Technology for the Field Application of Blast-furnace Slag Powder Concrete; Korea Land \& Housing Corporation: Seong-Nam, Korea, 2013.

19. Korea Ministry of Environment. Waste Processing Test Methods; Korea Ministry of Environment: Seoul, Korea, 2004.

20. Korea Ministry of Environment. Performance Standard for Environment Mark Certification (Permeableconcrete-EL245-2003/4/2012-36); Korea Ministry of Environment: Seoul, Korea, 2015.

21. American Society for Testing and Materials. Standard Test Method for Compressive Strength of Cylindrical Concrete Specimens; ASTM C39/C39M-15a; ASTM International: West Conshohocken, PA, USA, 2015.

22. American Society for Testing and Materials. Standard Test Method for Resistance of Concrete to Rapid Freezing and Thawing; ASTM C666/C666M-15; ASTM International: West Conshohocken, PA, USA, 2015.

23. Korea Ministry of Land, Infrastructure and Transport. Designing and Constructing Direction of Road Slope Planting; Korea Ministry of Environment: Seoul, Korea, 2009.

24. Ministry of Koran Environment. Environmental Official Testing Method; Ministry of Koran Environment: Seoul, Korea, 2015.

25. Han, S.H. Strength Characteristics of Concrete Containing Blast-Furnace Slag as Coarse Aggregate. J. KCI 2000, 12, 559-568.

26. Lanzoni, L.; Nobili, A.; Tarantino, A.M. Performance evaluation of a polypropylene-based draw-wired fibre for concrete structures. Constr. Build. Mater. 2012, 28, 798-806. [CrossRef]

27. Nobili, A.; Lanzoni, L.; Tarantino, A.M. Experimental investigation and monitoring of a polypropylene-based fiber reinforced concrete road pavement. Constr. Build. Mater. 2013, 47, 888-895. [CrossRef]

(C) 2016 by the authors; licensee MDPI, Basel, Switzerland. This article is an open access article distributed under the terms and conditions of the Creative Commons Attribution (CC-BY) license (http:/ / creativecommons.org/licenses/by/4.0/). 